Article

\title{
Educating Future Planners about Working with Children and Young People
}

\author{
Julie Rudner \\ Department of Social Inquiry, La Trobe University, 3552 Bendigo, Australia; E-Mail: j.rudner@latrobe.edu.au
}

Submitted: 3 April 2017 | Accepted: 14 August 2017 | Published: 26 September 2017

\begin{abstract}
Planning and urban design professionals should ensure they engage children/young people in their work so planning systems and strategic policy can be more inclusive of the needs and aspirations of children/young people. Yet practitioners do not necessarily view children/young people as legitimate stakeholders, and professionals do not necessarily have the skills to be inclusive. To shift current policy and practice, planners and designers need to be better educated so they can facilitate children's/young people's contributions as well as advocate effectively for systemic change. The UN Convention on the Rights of the Child and the UNICEF Child Friendly Cities provide legitimacy and direction for current and future professionals about why engagement with children/young people should be a fundamental part of professional practice. However, it's important that students and practitioners learn how to engage with children/young people ethically. A key starting point is the way in which education is constituted as ethical practice when conducting research and engagement activities with children/young people. Lansdown's (2011) requirements for ethical engagement are applied to reflexively evaluate the design and implementation of a university subject, delivered in Victoria, Australia, that trains future planners about how to work with children and young people.
\end{abstract}

\section{Keywords}

children; education; friendly city; young people; planning; urban design

\section{Issue}

This article is part of the issue "Promoting Children's Participation in Research, Policy and Practice", edited by Jo Aldridge (Loughborough University, UK).

(C) 2017 by the author; licensee Cogitatio (Lisbon, Portugal). This article is licensed under a Creative Commons Attribution 4.0 International License (CC BY).

\section{Addressing a Gap in Planning Education}

2017 marks the first year when young professionals who graduate from an Australian university, have only ever known corporatist forms of governance and planning. Neo-liberalism is normalised within the Victorian planning system (Gleeson \& Low, 2000; March, 2012), which largely means the public good and the public interest often equate to economic outcomes, rather than prosperity or wellbeing. Furthermore, assumptions that the public interest represents the aggregate of private interests are taken for granted. So, while current communicative approaches in planning can take stock of different issues and desires during planning processes, structural issues that affect political, social and economic participation or level of influence are uncontested (Fainstein, 2014; Murphy \& Fox-Rogers, 2015; Uitermark \& Nicholls, 2015). This is a significant issue if planners are to be at the forefront of change with regard to creating better cities for and with children, and thus necessitates appropriately educated planners.

This article evaluates the subject, Designing Children's Environments (DCE), which has been taught over the past six years. DCE was initiated to expose university students to issues that affect children/young people and their environments. A central tenet is that planners need to use their power by including children/young people in planning and decision-making about matters that affect their lives. Enrolled students learn about children's rights, ethics and research methods, and then work with children/young people on planning and design projects. A key objective is for students to appreciate the variety of conditions affecting children's/young people's wellbeing, as well as their agency, insight and competence when negotiating the world and participating in the public sphere (Cammaerts, Bruter, Banaji, Harrison, \& Anstead, 
2014; Chawla \& Heft, 2002; Vromen, Xenos, \& Loader, 2015). A child-centred approach influenced subject development, and its delivery. Students are encouraged to apply a child-centred approach to their work to ensure there is respectful engagement with children/young people and that they have a theoretical foundation to work with. Yet, competing demands and constraints when delivering this subject means objectives are not always met, which has ethical implications for doing these sorts of activities.

This subject is critically evaluated against Lansdown's (2011) elements of ethical research, which comprises matters such as training, child-sensitive and nondiscriminatory conduct and accountability. While the focus is on the subject itself, examples of students' work and reflections are also analysed to ascertain whether aims of awareness raising, practical skills, and commitment to inclusionary practices in the future can be achieved. It is important for future planners to be properly trained for working with children/young people, but there are potential issues if learning activities, such as engagement with children/young people, are exploitative. This can occur due to limited time allocated to relationship building with children/young people, their lack of participation in project development, and the potential for students to transform this experience into a codified approach to engagement. Lessons learned from this assessment will be beneficial to other educational designers.

\section{Promoting an Advocacy Approach in Planning}

The 1960 s and 1970 s ushered in a new role for planners as advocates for disadvantaged populations in response to increased awareness that individuals and groups experience their worlds differently. Since then, communicative planning has been codified into practice (Albrechts, 2015; Allmendinger \& Tewdwr-Jones, 2002). With the development of the UN Convention on the Rights of the Child (UNCRC) and the Unicef Child Friendly Cities Framework (CFCF) (International Secretariat for Child Friendly Cities, 2004), this has extended to children/young people. Unfortunately, its application has been adhoc, suggesting a need to increase awareness and competency amongst planners, who can change their practice, and in time the planning system.

While governance structures within signatory countries to the UNCRC should ensure children/young people contribute to decisions that affect them, it has not filtered through to all levels or spheres of government. In Victoria, as well as other parts of Australia, engagement with children/young people is still not an explicit mandate in planning law. Compliance with inclusive practices are dependent upon local government policy, availability of resources, and significantly-professional discretion. If professional commitment to including children/young people in planning processes can become more prevalent through education, then there is a possibility for creating systemic culture change.
This is a challenge for educators. Communicative planning draws attention to the validity of different perspectives at the expense of agitating for 'universal' goals or particular notions of the public good and social justice (Murphy \& Fox-Rogers, 2015; Uitermark \& Nicholls, 2015). Scholars' and practitioners' desires to reduce their position of power, recognise differences among their constituents, and treat them equally means they are not necessarily using their position effectively, or for those in need (Uitermark \& Nicholls, 2015). When all interests are treated equally, processes and outcomes are reproduced within existing power structures (Murphy \& Fox-Rogers, 2015; Uitermark \& Nicholls, 2015). With a stronger emphasis on planners to take a neutral position, they end up brokering competing interests rather than addressing inequalities that lead to inequity. As such, the political agendas of more powerful stakeholders are favoured (Allmendinger \& Tewdwr-Jones, 2002; March, 2012).

Fainstein (2010) argues that planners have power and they should use it. Structural inequalities that affect full participation in political, social and economic life need to be challenged. There is a dedicated and growing cohort of researchers and professionals who have, and continue to use, their expertise and resources to challenge processes and systems for disadvantaged groups, including children/young people (Aldridge, 2012; Chawla, 2002; Hart, 1992; Lynch, 1977, and others). This work is essential because children/young people generally lack access to, and leverage over, governance structures.

\section{Ethics of Engagement}

The UNCRC and the CFCF provide the regulatory support required when planners agitate for change. The Convention, to which 196 nations have signed, articulates the principles that support children's/young people's basic rights as well as governing responsibilities to ensure they are implemented. These are moral, political and contractual obligations that aim to create deep systemic change that will improve the lives of children/young people. Although the Convention and the Framework provide professionals with the regulatory rationale and principles needed to challenge the status quo, planners need to learn why and how the principles apply to their work, as well as the ethics of doing so.

The body of research that has emerged from scholars and practitioners since the 1960 s, provides a wealth of resources guiding research, teaching and planning practice. This corpus includes studies about children's/young people's citizenship and right to participate in decisions affecting their lives (Simpson, 1997; Tonucci \& Rissotto, 2001), their participatory competence (Chawla \& Heft, 2002; Frank, 2006), methods (Driskell, 2002; Horelli, 1998; Porter et al., 2010) and ethics (Aldridge, 2012; Christensen, 2004; Lansdown, 2011; Morrow \& Richards, 1996). Furthermore, there is a growing literature examining the pedagogical and practical outcomes that emerge when university students, children/young peo- 
ple and professionals work together on planning and design projects (Derr, 2015; Derr, Chawla, Mintzer, Cushing, \& Van Vliet, 2013; Torres, 2012).

Child-centred methodologies are the core of this scholarship and practice. Linking intellectual, political and practical goals, child-centred engagement in its ideal form, is research directed by children/young people from initiation through to analysis and reporting (Franks, 2011; Lansdown, 2011). Collaborative methods enable greater control by children/young people over the direction and methods of research, even when adult initiated (Franks, 2011; Lansdown, 2011). However, the ideal of child-led research is difficult to achieve in communitybased projects when there are competing demands from research institutions, funding bodies, and government agencies that affect project development and outcomes (Aldridge, 2007, 2012). These constraints often lead to truncated participation by children/young people, in which a child-centred approach facilitates children's/young people's ability to share their views and influence research outcomes, but not its development, analysis or application.

Lansdown's (2011) resource guide on children's/ young people's right to be heard, recognises that different forms of engagement can be still be productive and ethical, even when it is not child/youth directed. She identifies nine (2011, pp. 152-157) 'basic requirements for effective and ethical participation':

- Supported by training;

- Relevant;

- Transparent and informative;

- Facilitated with child-friendly environments and working methods;

- Voluntary;

- Safe and sensitive;

- Accountable;

- Inclusive;

- Respectful.

The communicative turn in planning tracks well against the need for relevance, transparency, accountability and inclusiveness, as these principles are well established (Healey, 1997; March, 2012), but variations in ethical considerations emerge in relation to voluntary participation. Planning theory and practice tends to focus on how to achieve diverse community representation, skills required to participate effectively in processes, how representation can be weighted in decision-making, and whose interests are most influential (March, 2012). These matters are important when engaging with children/young people, but there are additional issues of power and choice regarding their ability to provide consent or refuse participation in research activities. As Morrow and Richards (1996) identify, informed consent focuses on adult 'gatekeepers' and the need to protect children from harm, but formal ethics processes (not necessarily assessors) fail to recognise children's/young peo- ple's competence, right and choice to participate in research. Aldridge (2012) highlights that this is a thorny issue as protection is at the cross hairs of objective and subjective evaluation, and needs to be balanced with the prospective value of research and how it is conducted.

Sensitivity and inclusiveness are weak areas within the planning sphere that require further development (Sandercock, 2000; Sarkissian, Hirst, \& Stenberg, 2003), yet are essential when engaging or conducting research with children/young people. It is argued here, that this weakness creates ethical concerns when facilitating planning projects with children/young people. Patronising and discriminatory language and behaviour can arise due to adult socialisation, limited experience working with children/young people, and in many cases, limited experience with different ethnicities, cultures, religions and languages.

The overarching concept of commitment in childcentred scholarship and work poses another potential dilemma. It is dependent on adult stakeholders' willingness to dedicate time, energy and effort to project goals, supporting children's/young people's participation, and valuing their contribution with minimum interference. As indicated in the latter sections of this article, commitment can vary, which affects the balance between potential benefits of facilitating projects that bring university students, children/young people and planners together, and the costs of doing so.

\section{Methods Used to Develop This Article}

Lansdown's nine elements for effective participation provide a useful framework for exploring whether the conceptual basis for the subject and its structure, content, assessment and delivery conforms with recognised standards for ethical research and practice. The elements are also useful for identifying ethical issues in subject implementation, and opportunities for improvement. As noted, the critique is primarily reflexive; but includes examples of students' work and their reflections to illustrate key points.

Research associated with DCE is covered by La Trobe University human research ethics approval (No. 203413): pedagogical inquiry, children's/young people's experiences of their environments, and industry partnerships in planning practice. Students are informed about this research at the commencement of the subject, and they are sent a follow-up e-mail that requests their written consent to be a participant; draft publication materials are shared to obtain further consent. All student work presented here has their consent.

Data were selected from students who were enrolled in DCE 2013-2016. The total number (N) of students, and the number ( $\mathrm{n}$ ) of students who completed a self-reflection are: $2013(\mathrm{~N}=18, \mathrm{n}=9), 2014(\mathrm{~N}=8$, $\mathrm{n}=8), 2015(\mathrm{~N}=22, \mathrm{n}=18)$ and $2016(\mathrm{~N}=18, \mathrm{n}=4)$. The self-reflection is not marked, so some students did not complete this task. Anecdotal comments suggest chil- 
dren/young people enjoy working with the university students and sharing their ideas, but children's/young people's views about the design project were not formally assessed.

\section{Structure, Content and Delivery of DCE}

DCE was developed due to a desire to support children's/young people's participation and influence in planning, contribute toward cultural change in planning and policy that results in better environments for children/young people, assist government and community organisations with outreach, and address a gap in the curriculum by training future and existing planners to work with diverse populations. The aims are to raise students' awareness about the conditions affecting children's lives, provide practical child-centred research and engagement skills, and encourage a commitment to inclusionary practices. Content and delivery of DCE is an amalgamation of personal research experience, existing literature within children's studies, and discussions with colleagues.

Each year 20-25 students in their fourth and final year of their undergraduate planning degree (compulsory at this level) or in their first year of a postgraduate coursework planning degree, enrol in the subject. Students comprise domestic students, most of whom come from regional and rural areas and have AngloEuropean and Christian backgrounds, as well as a substantial number of international AusAid students from Asia and Africa.

Time constraints for delivering the subject are tight as DCE is offered during the first semester of every year (March to June). There are five days of face-to-face contact that last seven hours on each day. The first three days are delivered early in the semester. Students work with children/young people on the fourth day, and the fifth day comprises presentations and studio work to refine the projects. Class time is augmented by skillsdevelopment practicums that students complete prior to working with children/young people.

\subsection{Training}

Ensuring students are well prepared within a very short time for when they enter classrooms to work with children/young people is an ethical issue, especially since the subject is in a planning rather than education course. Therefore, DCE was designed to target particular knowledge and skills required for this purpose. There is strong alignment between intended learning outcomes, subject materials, activities and assessments; student learning is scaffolded to improve their knowledge, skills and confidence (Biggs \& Tang, 2011; Meyer \& Land, 2005).

As Table 1 shows, structurally, DCE addresses all key elements identified by Lansdown (2001) for effective training: enabling understanding and commitment to children's/young people's participation; access to training, tools and development opportunities, support and supervision, support for intercultural relations, respectful codes of conduct, open communication about concerns. But while the majority of students enjoy the educational activities in this subject (see Figure 1), enjoyment does not necessarily lead to transformative learning outcomes.

This is often revealed through completed assessments. In the policy practicum, students are asked to identify the top UNCRC articles they think apply to their future careers as planners and why. The most frequently cited articles are 31-right to participate in cultural life; 3-primacy of the best interest of the child; 12-freedom of expression about matters affecting the child, 23-right of mentally or physically disabled children to a full and decent life; and 24-right to the highest standard of health. Together, these articles reflect the key themes of spatial planning, communicative planning and inclusive design by ensuring children/young people can participate in public life regardless of age, gender, ethno-cultural and religious background, sexuality, and ability. Students' rationales for article selection focus on the 'how' rather than the 'why', which suggests that students are not connecting broader issues and supporting theory of children's/young people's rights and structural inequality to their understandings of planning practice.

In the play observation activity, some students provide detailed explanations about the games children play, young people's attitudes, and moments of physical or social cooperation or struggle. In contrast, many students are perfunctory in their observations, demonstrating much greater commitment to analysing the space than the people and their interactions. For this cohort, student descriptions of play were minimal, such as simply noting that children used the slide. Figure 2 provides an excerpt from one observation that provides a more descriptive observation of activities.

In a different example, some students are very creative when developing their engagement plans. They identify activities for different cultural and linguistic groups; they deliberately seek to meet aged-based needs; and they incorporate games, digital technologies, or training of young people to conduct their own research. However, others provide a rudimentary plan not too dissimilar to this subject's main project.

Students then participate in engagement activities with children/young people on a project to develop recommendations about improving their school site or neighbourhood. Children are those attending primary school, and young people comprise those attending secondary school (from about age 13). Implementation of the project presents the greatest opportunity for ethical issues to arise.

\subsection{Child-Friendly Environment, Working Methods, and Voluntary Participation}

Implementation of the subject meets Lansdown's (2011) minimum criteria for relevance, transparency and be- 
Table 1. DCE subject structure.

\begin{tabular}{|c|c|c|}
\hline \multicolumn{3}{|c|}{ Segment 1} \\
\hline Purpose & Content & Activities \\
\hline $\begin{array}{l}\text { Unsettle students' cultural } \\
\text { assumptions of childhood/ } \\
\text { adulthood. } \\
\text { Help students identify how the } \\
\text { planning system and } \\
\text { professional practice has } \\
\text { reinforced particular notions } \\
\text { of children/young people over } \\
\text { time. }\end{array}$ & $\begin{array}{l}\text { Traces historical connections } \\
\text { between planning, health and } \\
\text { governing children/young people's } \\
\text { moral and physical development. } \\
\text { Conceptions of childhood over time } \\
\text { (James, Jenks, \& Prout, 1998; } \\
\text { Valentine, 2004). } \\
\text { Children's/young people's } \\
\text { citizenship (Hart, 1992; Iveson, } \\
\text { 2006; Simpson, 1997). }\end{array}$ & $\begin{array}{l}\text { Lectures, discussions and videos. } \\
\text { Practicum: Short answer essay critiquing the } \\
\text { claim that there is a false dichotomy between } \\
\text { notions of child and adult; critical policy } \\
\text { comparison to identify how different local } \\
\text { government documents address matters } \\
\text { affecting children/young people; and } \\
\text { selection of key articles from the UNCRC that } \\
\text { students believe are most integral to planning, } \\
\text { accompanied by an explanation for selection. }\end{array}$ \\
\hline
\end{tabular}
inequalities re: economic, cultural/ethnic, ability, gender, sexuality.

Segment 2

\begin{tabular}{|c|c|c|}
\hline Purpose & Content & Activities \\
\hline \multirow{7}{*}{$\begin{array}{l}\text { Develop students' knowledge } \\
\text { and skills for working with } \\
\text { children/young people. } \\
\text { Develop students' } \\
\text { understanding of child-centred } \\
\text { and ethical approaches to } \\
\text { engagement. }\end{array}$} & \multirow{2}{*}{$\begin{array}{l}\text { Theories of children's/young } \\
\text { people's development are } \\
\text { introduced: psychological, cognitive, } \\
\text { emotional, linguistic, social, physical, } \\
\text { and independence. (Centre for } \\
\text { Learning Innovation, 2006, covers } \\
\text { key theorists e.g., Brofenbrenner, } \\
\text { Erikson, Piaget and Vygotsky). }\end{array}$} & $\begin{array}{l}\text { Activities: Students identify how development } \\
\text { theories would alter students' approach to } \\
\text { different planning and urban design scenarios. }\end{array}$ \\
\hline & & $\begin{array}{l}\text { Students write essays, conduct photo } \\
\text { elicitation exercises with each other, } \\
\text { complete questionnaires, engage with GIS } \\
\text { mapping and drawing. }\end{array}$ \\
\hline & \multirow{5}{*}{$\begin{array}{l}\text { Research methods for engaging } \\
\text { children/young people are } \\
\text { introduced. (Driskell, 2002; Freeman } \\
\text { \& Tranter, 2012; Morrow, 2001; } \\
\text { Santo, Ferguson, \& Tripple, 2010). } \\
\text { University ethics processes and the } \\
\text { specific application for the subject } \\
\text { are reviewed. }\end{array}$} & $\begin{array}{l}\text { Students attend a Learning Landscapes and } \\
\text { learning to play program conducted by staff at } \\
\text { a Melbourne based children's garden. }\end{array}$ \\
\hline & & $\begin{array}{l}\text { Students attend a seminar with a renowned } \\
\text { landscape architect who specialises in }\end{array}$ \\
\hline & & children's play spaces. \\
\hline & & $\begin{array}{l}\text { Practicums: Development of an engagement } \\
\text { plan for a multicultural local government area } \\
\text { in response to a mock brief. }\end{array}$ \\
\hline & & $\begin{array}{l}\text { Field observations of children/young people } \\
\text { playing. }\end{array}$ \\
\hline
\end{tabular}

Segment 3

\begin{tabular}{|c|c|c|}
\hline Purpose & Content & Activities \\
\hline $\begin{array}{l}\text { Develop students' awareness } \\
\text { of the continuities and } \\
\text { differences over time across } \\
\text { settlement types, and across } \\
\text { countries with regard to } \\
\text { planning for and with children. }\end{array}$ & $\begin{array}{l}\text { Using case studies, students learn } \\
\text { about the relationship of } \\
\text { children/young people with the } \\
\text { built form, active transport, physical } \\
\text { activity, social relations and risk } \\
\text { (Lynch, 1977; Malone, 1999; Owens, } \\
\text { 1994; Rudner, 2012). }\end{array}$ & $\begin{array}{l}\text { Activity: Students engage with children/young } \\
\text { people about their outdoor school spaces or } \\
\text { neighbourhood. } \\
\text { Production of a masterplan and design in } \\
\text { response to engagement activities. }\end{array}$ \\
\hline
\end{tabular}




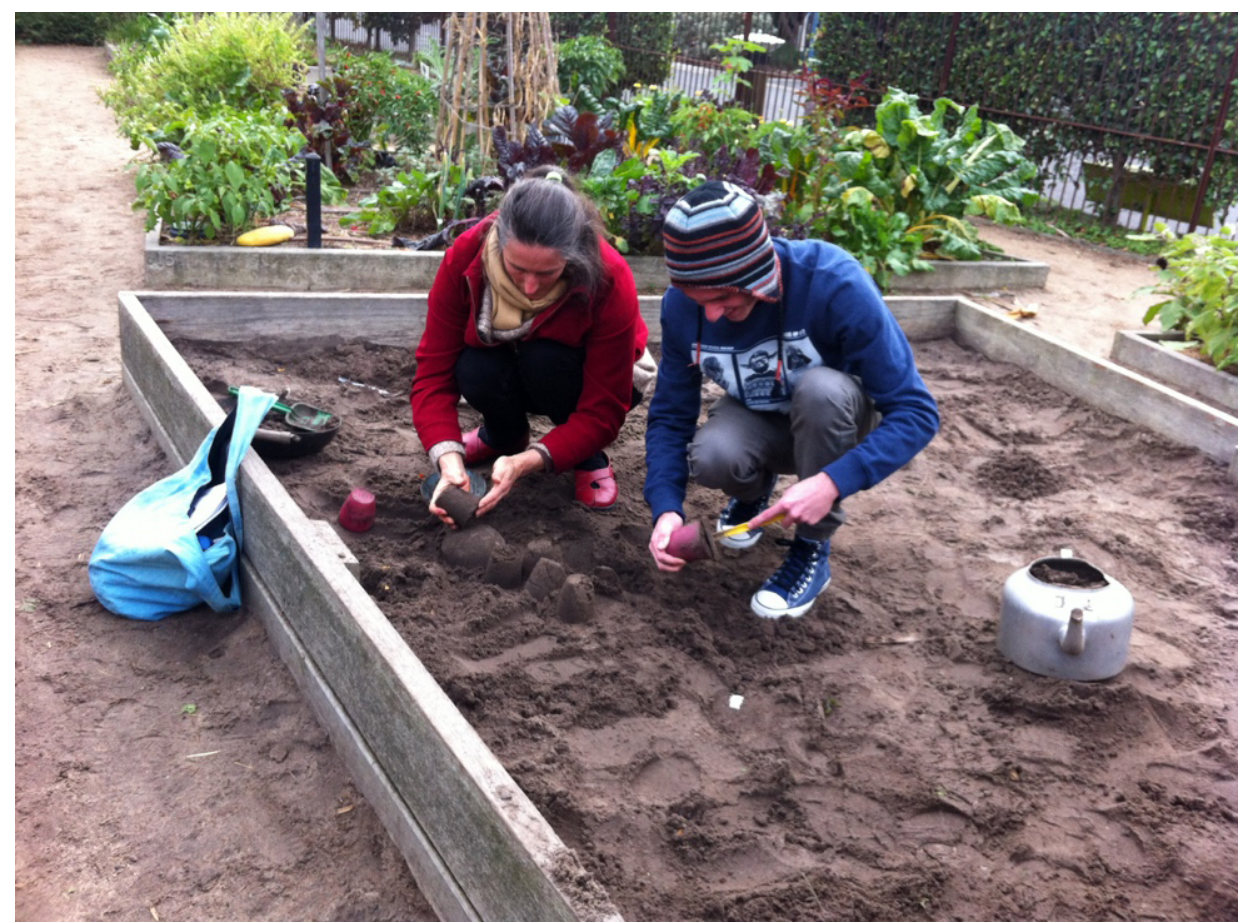

Figure 1. Students learning how to play at the Ian Potter Foundation's Children's Garden.

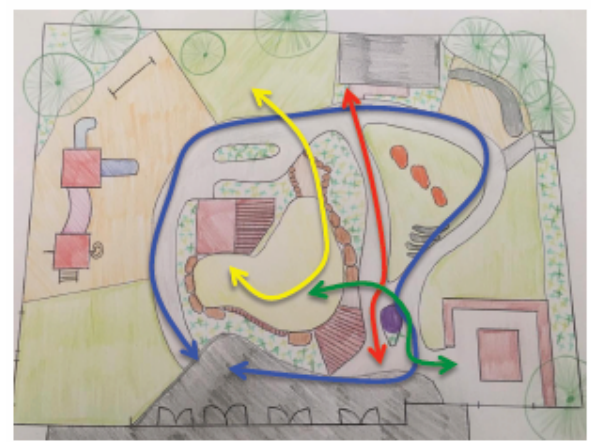

\begin{abstract}
Movements between locations
Throughout the observation process, it became clear that children frequently moved back and forth between locations, either moving from one activity to another or repeating the same activity or movement. Four key movement paths were developed, these include:

- Blue Pathway - Here children (normally in the older age brackets) chased each other. Those who had access to tricycles rode them around and around the circle. In addition children who play alone often walked around and around the path, picking up leaves or skipping.

- Red Pathway - Boys, discovering the decline from the shed to the veranda, used this pathway. These boys rode tricycles and scooters down the slope and then push them back up again to start over.

- Yellow Pathway - Was majorly used by the younger age groups being observed. Here children moved between the sandpit and adjacent shelter to the AstroTurf area, which was covered with, leaves and sticks. Collecting these sticks they brought them back to other children playing and used them in a shop like play or as decorative pieces on their sand castles. Children in the yellow pathway were often intercepted with those using the blue pathway and became cautious when crossing

- Green Pathway - The children who used this pathway moved between the sandpit and the sheltered sitting area, more often than not meeting up with their parents or guardians, before going off and playing again. These children were also seen using the collected sticks from the sandpit to further create music on the water tank.
\end{abstract}

Figure 2. Excerpt from student observation assessment.

ing informative, and largely achieves ethical requirements regarding environment, working methods and voluntary participation. Council, university staff, students and teachers are generally committed to the process and achieving positive outcomes. Open communication is supported by ethics research processes that include the need for information statements and consent forms, negotiation of activities and project requirements between different stakeholders and the attitude of stakeholders. Issues can still arise, however, around commitment, voluntary participation and time. The project process is presented in Figure 3.

Procedurally, Council staff conducting strategic policy development contact the subject lecturer to request assistance with their engagement activities. The subject lecturer then gains permission from principals and teachers from selected schools to do the project, and research activities are jointly determined. University students visit the school to work with the children/young people. Children/young people are reminded about, or introduced to the design process, the voluntary nature of participation, how their contribution will be used by Council staff and students, and their ability to stop participating at any time. During the contact session, children/young people "draw on their knowledge, skills and abilities" (Lansdown, 2011, p. 153) to provide insight about the places where they live, their likes/dislikes of the site or their neighbourhood, their travel modes, their obser- 


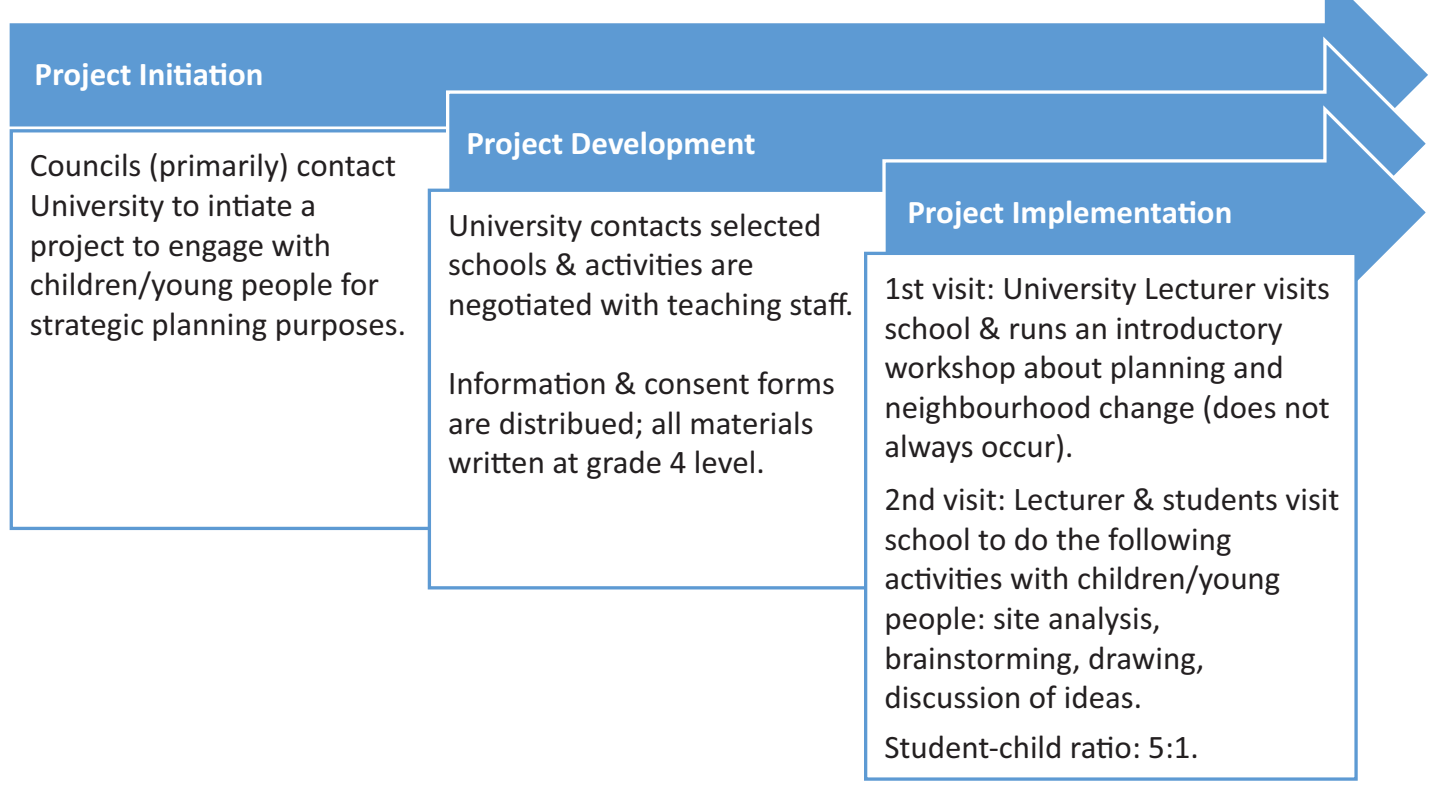

Figure 3. Design project process.

vations of how their peers' use the site, how the site changes in different seasons, etcetera. The session concludes after the children/young people have presented their ideas to each other, participating teachers and the Council representative.

Council staff and teachers work within a childcentred paradigm due to their training and professional role, but their participation suggests different levels of commitment to the activities. Council staff, who are primarily from social services sections of local government agencies, are dedicated to the project for purposes of strategy development through the inclusion of children's/young people's views; they assist during data collection, and translate children's/young people's ideas into Council strategic plans based on the university students' reports.

Teachers' participation is more ambivalent, depending on their degree of choice to support the project in relation to their principal's directions, their ability or willingness to connect activities to curriculum requirements, and work pressures. They might be very supportive by augmenting the project with class room activities before and after the engagement session, participate only during the contact session, or use the time during engagement activities to do their own work.

Like teachers, the voluntary nature of children's/ young people's participation is difficult to monitor; both are influenced by bureaucratic hierarchies, but children/young people are also affected by the greater authority and power held by adults. Since the school visit is usually confined to 50 minutes (sometimes 75 minutes) to fit with curriculum requirements, there is a high degree of adult direction. Fortunately, discussions with children/young people during contact sessions, and observation of their engagement suggests participation is voluntary, and those who want to stop, do so.
In contrast, university student participation is compulsory. Their level of commitment to the subject activities and to child-centred approaches ranges. Although it is worth noting that many students indicated they would have liked to work with children/young people over a series of contact sessions so they could jointly develop the research program with children/young people.

\subsection{Safety, Sensitivity and Accountability}

The importance of safety, sensitivity and accountability to ethical engagement is ensured through formal and organisational (university, Council, school) structures but competence varies amongst stakeholders. The subject coordinator, Council staff and teachers are trained in child protection regulation and ethics, as well as those students who work or volunteer with children/young people in other areas of their lives. All adults have working with children checks and each student cohort is registered with the ethics committee.

Even though risk, safety and sensitivity are integrated into subject materials and assessments, and issues are discussed further with students prior to engagement with children/young people, there is potential for error. It can be difficult for some students to grasp some of the issues, due to their limited experience. Students can be patronising, or reveal their own cultural socialisation through bias and expectation. Having a cohort of multinational, ethnically and religiously diverse students helps during the preparation phases as cross-cultural issues can be discussed, but this does not preclude insensitive conduct from arising.

Photography is a troublesome area to monitor, even when teachers identify which children/young people cannot be in photos. Therefore, students refrain from taking photos in which children/young people can be iden- 
tified e.g.: only taking photos from behind or from a distance. This is not always possible, as children/young people like to be in images and request to use students' cameras/phones to take photos. To address this, students upload photos onto the closed learning management system for collation before sending to the participating school. Subsequently all images that include children/young people are deleted from all devices, and no photos in which children/young people can be identified are used in reports.

An integral part of the process is timely and respectful acknowledgement of children's/young people's participation. Within two weeks of the engagement, students provide one design image per group to send to teachers at the school for distribution. The main report is provided to the Council staff member and teachers three weeks later. The masterplan report and play space design, which are written at children's/young people's level of comprehension, includes justifications that clearly acknowledge the children's/young people's ideas and how they have been used in the report. Children/young people receive participation certificates jointly signed by the subject coordinator and the Council staff member.

Accountability is the weakest aspect of the subject. It can be difficult for teachers to create space within their curriculum. Only one school elected to have a third visit, during which proposed designs were presented to the children/young people for further feedback. In this session, electronic hand held clickers were used to conduct an instant survey of children's/young people's assessment of the ideas and to guide discussion. Distribution of the report to children/young people cannot be guaranteed as this process relies on teachers.

Feedback is sought from teachers but is rarely received. Three schools out of ten provided feedback, which was positive: 1) teachers from one school wanted to make the project an annual activity; 2) one teacher e-mailed to indicate $s /$ he was impressed by the quality of the students work; 3 ) one principal reported twice about the project through the school's newsletter.

For personal/lecturer accountability, this subject has been audited by an expert in children's environments. Plus, students complete a self and group evaluation that identifies their contribution to the project, as well as their perceptions about the level and quality of contribution of their group members. Every year the subject and engagement practices are improved because each project creates new learning opportunities.

\subsection{Respectful and Inclusive}

According to Lansdown's (2011) criteria, project engagement activities should be inclusive and respectful. Although teachers select which children/young people participate, participants are usually selected based on their particular grade within a school e.g. all grade fours. Furthermore, non-discriminatory participation processes are promoted; teachers are encouraged to include children/young people, irrespective of their ability, ethnicity, language, behaviour patterns, and so forth. Inclusion is enhanced by the student cohort, which reflects the diversity of children/young people. When children/young people do not provide consent forms to participate in the research, then priority is placed on their engagement in activities, which means children's/young people's ideas for that particular school cannot be reported in scholarly publications.

Data below comprise excerpts from student responses to a six question survey conducted at the end of the subject that queried their comfortability, likes and dislikes about working with children/young people, what they did well or poorly, and key skills for working effectively with children/young people. Comments from students suggest that engaging with children/young people through the project activity is an important method for learning about respectful and inclusive engagement, since insights and skills gained from preparation activities are not the same as learning from experience. Importantly, quotations indicate an effort to conduct ethical engagement and grapple with dilemmas about ensuring inclusion. Figure 4 illustrates students working with young people.

Students' assumptions about children/young people are often confronted during the contact session. Many students are surprised about children's/young people's ability to participate in the design exercise, articulate and draw their ideas. International students from non-AngloEuropean nations find the experience interesting as this type of activity is not common in their countries. The following comment highlights students' surprise at the positive nature of the engagement:

This process of involving children in planning is a new thing and interesting to me, from the place I came from, this is not done.... I was amazed to hear the comments they make for the improvement of their grounds; they were very positive about the planning process, positively contributed their ideas and also their ability to put their thoughts into drawings. (IM, female postgraduate student, Tanzania)

The majority of students demonstrate efforts to take a child-centred approach to the engagement. They actively seek to have 'honest' and 'authentic' interactions and to help children/young people feel comfortable, safe and respected in the process, as the following quotation illustrates:

I could have taken better notes! In fact, recording the children's voices with a recorder would have been the best thing because trying to represent their authentic voice needs clear notes within context and it was happening so fast that I am sure I missed things that would have helped with the meaning of their words....I really get that they are the experts in their 


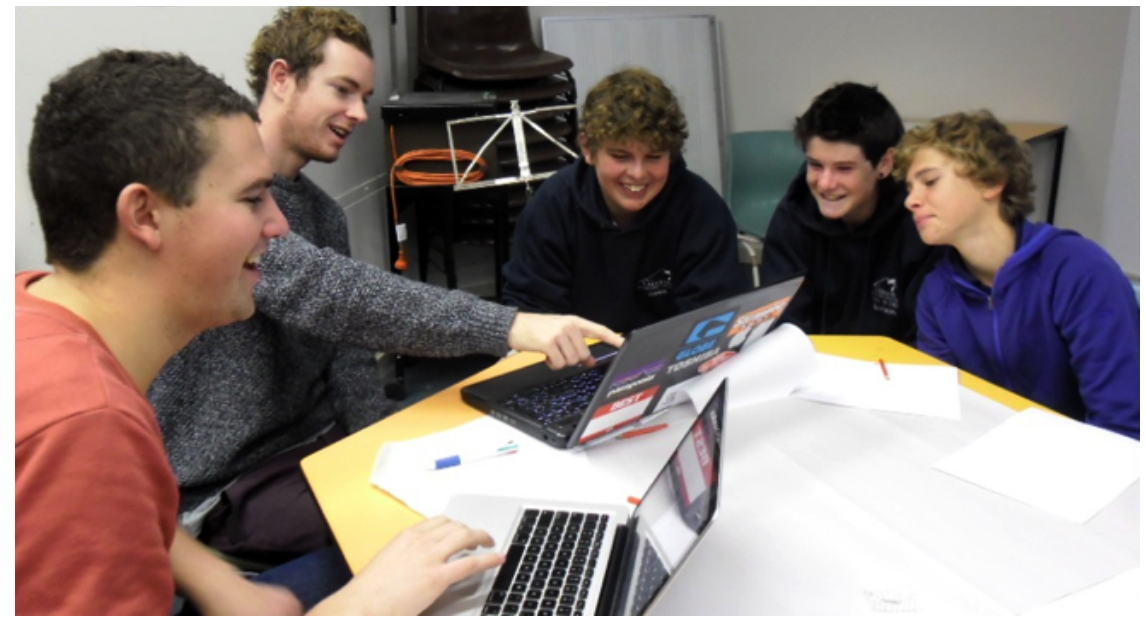

Figure 4. School students visit the university for the project. (Image by Marion Drummond, 2012).

lives too... (CL, female postgraduate, Mediterranean heritage, Australia)

Depending on group dynamics, some students find it easier than others to be child-centred and to elicit engagement from children/young people. A few students grapple with their status as adults and researchers in relation to the uncertainty of providing structure and order. They want to encourage and guide children/young people, but students do not want to direct the children too much, or dampen their spirits when they contribute.

When students became unruly, it was difficult to know the bounds of my own personal authority in the situation as we were essentially guests on school grounds and not there in any disciplinary capacity. Although I had no problems with my group, in the classroom when all students were together there were instances of students being disruptive and I was slightly uncertain as to how to handle this and just tried to keep them engaged. (RW, male postgraduate, AngloEuropean heritage, Australia)

Balancing power is complicated by a desire to ensure that all children/young people participate. Students need to use skills that ensure all children/young people are valued because some are gregarious, and others are quiet or can be silenced. Managing individual and group behaviour is a common area of improvement identified by students.

\subsection{Systemic Change?}

DCE was developed so it challenges students to explore how planning relates to children's/young people's lives, and to understand children's/young people's views and experiences of their cities. A particular focus is to provide the knowledge and skills required to conduct ethical research and practice with children/young people. Lansdown's (2011) ethical requirements for research is a useful framework by which to review the aims and objectives of community-based design subjects in which university students work with children/young people, as it establishes basic standards for engagement and reveals areas for improvement. The design, content, activities and assessments of DCE are generally successful at raising student awareness and developing their practical skills, but the evaluation process is a reminder that the quality of commitment, time, energy and effort has greater bearing as to whether the types of activities presented here are conducted ethically.

In the shorter term, the value and potential benefit of DCE needs to be negotiated each year with participating students, Council staff, teachers and children/young people. Shifting dynamics require nuanced and flexible reading of different personalities, priorities and dedication. Transparent, informative communications are essential, but are not always easy to achieve. There are gaps in expectations between different stakeholders that require management, and the characteristics of each student cohort is unique. For example, students' capabilities can be improved through adjustments to the subject, but external pressures on students as well as differing levels of commitment for engaging with the learning materials means there is a constant question about whether engagement activities should take place. Does it matter if some students do not have the time or do not have the interest to think more deeply about their work? Does engagement with children/young people need to be matched by dedication to the preparatory stages of the subject?

These questions lead to broader dilemmas about the ethics of engagement activities with children/young people when there are multiple goals in these sorts of exercises. From observations, it appears that working with university students is exciting for children/young people and they are happy to share their ideas. Yet, they are also being co-opted into an educational program that is primarily aimed at improving university students' competencies. Similarly, children/young people have an op- 
portunity to contribute to Council strategies, but their participation is also being used to legitimize Council decision-making regardless of actual material outcomes (March, 2012).

Compared to other examples of projects that bring university and children/young people together (Derr, 2015; Derr et al., 2013; Torres, 2012), DCE appears to be more consultative than collaborative (Hart, 1992; Lansdown, 2011) due to fewer staff, Council timelines, and teaching pressures on participating schools. This means students are unlikely to distinguish between consultation and collaboration. Working with one school to develop a strong relationship over time could facilitate more collaborative approaches to project work, and reduce some of the risks involved during engagement activities. However, this needs to be counterbalanced against the potential for children/young people to influence local government policy that does result in material change.

In terms of future benefits, DCE contributes to longerterm goals of cultural change within planning since there will be more professionals in the workplace who are aware of, and able to fulfil their responsibilities under the UNCRC. Indeed, four graduates who completed the subject to date, have initiated Council projects that aim to engage children/young people in planning processes. However, there is the potential that student activities in this subject become a benchmark rather than a starting point for engagement with children/young people. Therefore, it is important to reinforce issues of commitment, curiosity and creativity, and ensure students access a variety of example engagement activities so they have a better understanding of other approaches, methods and outcomes.

Importantly, the review lead to the significant realisation that DCE fits well within existing planning processes, but it does not do enough to help students challenge structural issues that situate children's/young people's engagement outside of regular planning practice. The participating Council staff are located in the community development or maternal and child health area, rather than planning and design; furthermore, they are often unable to convince planning and design staff to participate in engagement activities. As future professionals, students will have the power to identify and advocate for social justice for children/young people, but possibly without the benefit of work place role models to guide them.

Achieving more significant change with the planning system requires planners to take stronger advocacy positions, but it is difficult to create learning experiences that assist them to confront the planning system itself. University subjects can help students gain knowledge and skills to advocate, but the responsibility rests with their own commitment to working with children/young people to create change. This means that planners as knowledge producers, policy developers and plan implementers, need to negotiate the paternalising and empowering aspects of their roles and functions. As Uiter- mark and Nicholls (2015, pp. 33-34) argue, "It is a genuine dilemma because status, knowledge, and skills are necessary in struggles for equality but the unequal distribution of these resources produces new hierarchies during the process of achieving equality".

Participation enables children/young people to inform professionals and other stakeholders about their successes, struggles, and aspirations for their lives. When acted upon, children/young people can contribute to better policies that improve health, education, legal rights and safety and reduce discrimination and violence. Importantly, the UNCRC and CFC legitimise children's/young people's participation and influence in planning practice, thus enabling planners to develop a strong narrative that clearly explains how a focus on children's/young people's rights contributes to the public good and the public interest. Systemic and cultural change in planning is likely to occur when consistent application of practitioners' knowledge and expertise at engaging children/young people is pervasive.

\section{Acknowledgements}

Thank you to La Trobe University students 2013-2017, and the local government Councils, principals, teachers and children/young people who, through my good fortune, participated in various planning projects and helped me to learn as much as I have.

\section{Conflict of Interests}

The author declares no conflict of interest.

\section{References}

Albrechts, L. (2015). Breaking out of the box: Ingredients for a more radical planning. Procedia: Social and Behavioral Sciences, 184, 104-110. doi:http://dx.doi.org/10.1016/j.sbspro.2015.05.063

Aldridge, J. (2007). Picture this: The use of participatory photographic research methods with people with learning disabilities. Disability \& Society, 22(1), 1-17. doi:10.1080/09687590601056006

Aldridge, J. (2012). Working with vulnerable groups in social research: Dilemmas by default and design. Qualitative Research, 14(1), 112-130. doi:10.1177/ 1468794112455041

Allmendinger, P., \& Tewdwr-Jones, M. (Eds.). (2002). Planning futures: New directions for planning theory. London, UK: Routledge.

Biggs, J. B., \& Tang, C. (2011). Constructively aligned teaching and assessment. Teaching for quality learning at University. Maidenhead: McGraw-Hill Education.

Cammaerts, B., Bruter, M., Banaji, S., Harrison, S., \& Anstead, N. (2014). The myth of youth apathy: Young Europeans' critical attitudes toward democratic life. American Behavioral Scientist, 58(5), 645-664. doi:10.1177/0002764213515992 
Centre for Learning Innovation. (2006). A basic introduction to child development theories. Sydney: NSW Department of Education and Training. Retrieved from http://Irrpublic.cli.det.nsw.edu.au/IrrSecure/Sites/ LRRView/7401/documents/theories_outline.pdf

Chawla, L. (2002). Growing up in an urbanising world. London: Earthscan.

Chawla, L., \& Heft, H. (2002). Children's competence and the ecology of communities: A Functional approach to the evaluation of participation. Journal of Environmental Psychology, 22, 201-216.

Christensen, P. H. (2004). Children's participation in ethnographic research: Issues of power and representation. Children \& Society, 18(2), 165-176. doi:10.1002/chi.823

Derr, V. (2015). Integrating community engagement and children's voices into design and planning education. CoDesign, 11(2), 119-133. doi:10.1080/ 15710882.2015.1054842

Derr, V., Chawla, L., Mintzer, M., Cushing, D., \& Van Vliet, W. (2013). A City for all citizens: Integrating children and youth from marginalized populations into city planning. Buildings, 3(3), 482.

Driskell, D. (2002). Young people's participation. Creating better cities with children and youth: A manual for participation (pp. 32-47). London: Earthscan.

Fainstein, S. S. (2014). The just city. International Journal of Urban Sciences, 18(1), 1-18. doi:10.1080/ 12265934.2013.834643

Frank, K. I. (2006). The potential of youth participation in planning. Journal of Planning Literature, 20(4), 351-371.

Franks, M. (2011). Pockets of participation: Revisiting child-centred participation research. Children \& Society, 25(1), 15-25. doi:10.1111/j.1099-0860.2009. 00258.x

Freeman, C., \& Tranter, P. (2012). Children and their urban environment. Taylor and Francis.

Gleeson, B., \& Low, N. (2000). Australian urban planning: New challenges, new agendas. Crows Nest: Allen and Unwin.

Hart, R. (1992). Children's participation: From tokenism to citizenship. Florence: UNICEF International Child Development Centre. Retrieved from http://www. unicef-irc.org/publications/pdf/childrens_participa tion.pdf

Healey, P. (1997). Collaborative planning: Shaping places in fragmented societies. London: MacMillan Press Ltd.

Horelli, L. (1998). Creating child-friendly environments: Case studies on children's participation in three European countries. Childhood, 5(2), 225-239.

International Secretariat for Child Friendly Cities. (2004). Building child friendly cities: A framework for action. Florence: UNICEF Innocenti Research Centre. Retreived from http://childfriendlycities.org/wpcontent/uploads/2013/04/pdf/BuildingCFC_AFrame workforaction_en.pdf
Iveson, K. (2006). Cities for angry young people? From exclusion and inclusion to engagement in urban policy. In B. Gleeson \& N. Sipe (Eds.), Creating child friendly cities: Reinstating kids in the city (pp. 49-65). Oxon: Routledge.

James, A., Jenks, C., \& Prout, A. (1998). Theorizing childhood. Cambridge, UK: Polity Press.

Lansdown, G. (2011). Every child's right to be heard: A resource guide of the UN Committee on the Rights of the Child general comment no. 12. London: Save the Children UK. Retrieved from https://www.unicef.org/ adolescence/files/Every_Childs_Right_to_be_Heard. pdf

Lynch, K. (1977). Growing up in cities: Studies of spatial environment of adolescence in Cracow, Melbourne, Mexico City, Salta, Toluca, and Warszawa. Paris: UNESCO, Massachusetts Institute of Technology.

Malone, K. (1999). Growing up in cities as a model of participatory planning and 'place-making' with young people. Youth Studies Australia, 18(2), 17-33.

March, A. (2012). The democratic plan: Analysis \& diagnosis. Farhham and Burlington: Ashgate Publishing Ltd.

Meyer, J. F., \& Land, R. (2005). Threshold concepts and troublesome knowledge (2): Epistemological considerations and a conceptual framework for teaching and learning. Higher Education, 49(3), 373-388. doi:10.1007/s10734-004-6779-5

Morrow, V. (2001). Using qualitative methods to elicit young people's perspectives on their environments: some ideas for community health initiatives. Health Education Research, 16(3), 255-268. doi:10.1093/ her/16.3.255

Morrow, V., \& Richards, M. (1996). The ethics of social research with children: An overview. Children \& Society, 10(2), 90-105. doi:10.1111/j.1099-0860. 1996.tb00461.x

Murphy, E., \& Fox-Rogers, L. (2015). Perceptions of the common good in planning. Cities, 42, Part B, 231-241. doi:http://dx.doi.org/10.1016/j.cities.2014.07.008

Owens, P. E. (1994). Teen places in Sunshine, Australia: Then and now. Children's Environments, 11(4), 42-54.

Porter, G., Hampshire, K., Bourdillon, M., Robson, E., Munthali, A., Abane, A., \& Mashiri, M. (2010). Children as research collaborators: Issues and reflections from a mobility study in sub-Saharan Africa. American journal of community psychology, 46(1/2), 215-227. doi:10.1007/s10464-010-9317-x

Rudner, J. (2012). Public knowing of risk and children's independent mobility. Progress in Planning, 78(1), 1-53.

Sandercock, L. (2000). When strangers become neighbours: Managing cities of difference. Planning Theory \& Practice, 1(1), 13-30. doi:10.1080/ 14649350050135176

Santo, C. A., Ferguson, N., \& Tripple, A. (2010). Engaging urban youth through technology: The Youth Neigh- 
borhood Mapping Initiative. Journal of Planning Education and Research, 30(1), 52-65.

Sarkissian, W., Hirst, A., \& Stenberg, B. (2003). Reconceptualising community participation. In Community participation in practice: New directions (pp. 1-16). Perth: Murdoch University Institute for Sustainability and Technology Policy.

Simpson, B. (1997). Towards the participation of children and young people in urban planning and design. Urban Studies, 34(5/6), 907-925.

Tonucci, F., \& Rissotto, A. (2001). Why do we need children's participation? The importance of children's participation in changing the city. Journal of Community \& Applied Social Psychology, 11(6), 407-419.

Torres, J. (2012). Participation as a pedagogy of com- plexity: Lessons from two design projects with children. Urban Design International, 17(1), 62-75. doi:http://dx.doi.org/10.1057/udi.2011.18

Uitermark, J., \& Nicholls, W. (2015). Planning for social justice: Strategies, dilemmas, tradeoffs. Planning Theory, 16(1), 32-50. doi:10.1177/ 1473095215599027

Valentine, G. (2004). Public space and the culture of childhood. Aldershot: Ahsgatte Publishing Limited.

Vromen, A., Xenos, M. A., \& Loader, B. (2015). Young people, social media and connective action: From organisational maintenance to everyday political talk. Journal of Youth Studies, 18(1), 80-100. doi:10.1080/13676261.2014.933198

\section{About the Author}

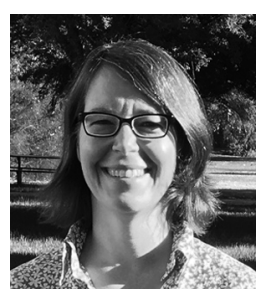

Julie Rudner (PhD) explores interactions between policy, place and people, with a particular focus on how children, young people and people from different ethno-cultural and religious backgrounds use, view and experience their environments. Her main interest is how we create a 'public knowing' of risk, safety and belonging that encourages or limits people's freedom to use public space confidently. She supports active citizenship through community participation in planning. 